\title{
CORPORATE HUMAN RIGHTS RESPONSIBILITY AND \\ MULTINATIONALITY IN EMERGING MARKETS - FROM A DEVELOPING NOTION TO THE LEGAL DIMENSION
}

\section{Sascha-Dominik Bachmann}

Assessor Juris (LMU, Germany), LL.M (Stellenbosch), LL.D (Johannesburg)

Reader in International Law, School of Law, University of Lincoln

\section{Vijay Pereira}

LL.B (Hons) B'Com (Hons) MBA (Bombay, India),

MSc (International HRM) (Portsmouth UK)

Senior Lecturer in Business, Portsmouth Business School, University of

Portsmouth 


\section{Research Aim and Objective}

- The principal aim of this article is to highlight the evolving concepts and ideas of Corporate Human Rights Responsibility (CHRR) under international law and how it relates to other concepts of corporate responsibility.

- The main research objective of this paper is to examine the concept of 'Corporate Human Rights Responsibility' in the context of Multinationality in emerging markets such as China and India and thereby to assess this notion through the prism of the legal dimension. 


\section{Conceptual Framework}




\section{Rationale and Contribution}

- The point of departure is the observation that there is the need to close an existing impunity gap of Western and emerging market MNCs' complicity in Human Rights violations committed in the developing world.

- Two case studies from India and China highlight the present accountability gap.

- This article understands that the key issue with CHRR is the absence of a binding regime of binding norms, paired with the observation that implementation and enforcement issues seriously hamper any such development.

- Based on related initiatives such as CSR and Good Corporate Practice this article calls for an approach which is borne by a multitude of stakeholders 


\section{The cases}

- The Bhopal tragedy, India- 'The 1984 gas leak in Bhopal was a terrible tragedy that understandably continues to evoke strong emotions even 27 years later', this statement from the 'horse's mouth' (Union Carbide Corporation's (UCC) website, 2012) is an understatement. UCC was one of the first U.S. companies to invest in India......

- Melamine-Milk scandal, China- In 2008, dangerously high levels of the industrial chemical melamine in powdered baby milk and other dairy products in China sparked worldwide safety concerns (BBC website, 2008). On the $10^{\text {th }}$ of September 2008, Chinese officials and the media first reported that 14 babies fell ill in Gansu province over the previous two months. Reports indicated that all drank the same brand of milk powder and were being reported around China. It was not until the $12^{\text {th }}$ of September 2008, that the Sanlu Group admitted that its milk powder was contaminated with the toxic chemical melamine. The New Zealand dairy cooperative Fonterra owned a 43\% stake in Sanlu...... 


\section{The Legal Dimension-}

Basic Features of US Human Rights Litigation against Corporations

UNIVERSITY OF

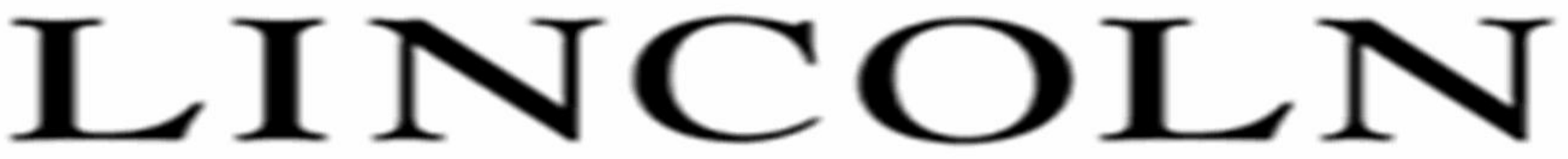




\section{Rationare and Ovenview}

$>$ HUMAN RIGHTS LITICATIÔN refers to:

- A form of transnational civil itigation developed in the USA since the 1980ies as scealled which

- civil litigation for internationallaw torts arising out of breaches of international (public) la wand human rights law

- Greatestimpact in connection witb/mass torts action for human rights abuses $>$ Holocarst Jawsuits and terrorism -> In re Terrorism Attacks on September 11

- High damages including punitive damages as deterrence Notion of indirect corporate liability for AIDING and ABETI IING innan Rights a uses 


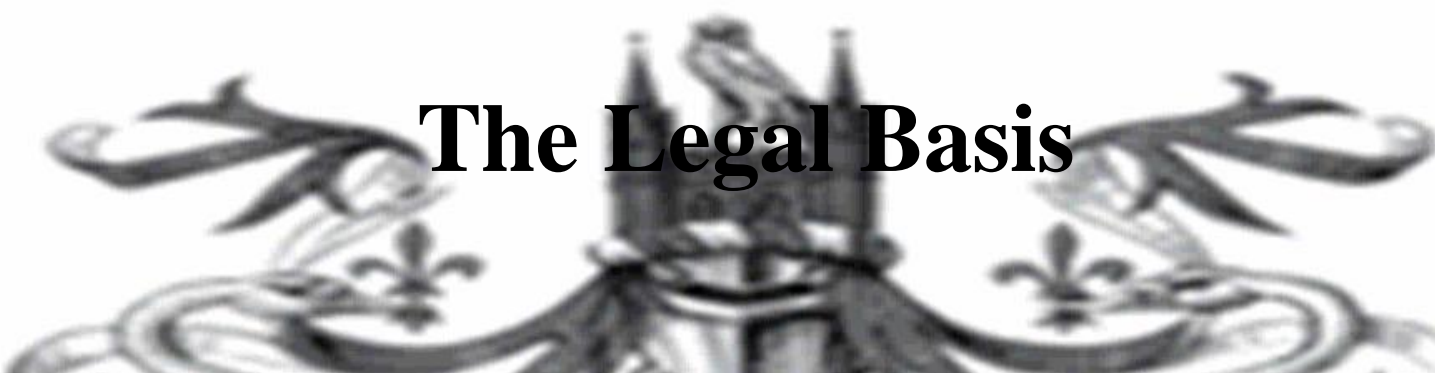

- 1. Alien Tort Statute (ATS)-formerly known as ATCA

- 2. Torture Victim protection Act (TVPA)

- 3. The Eoreign States Immunities Act (ESIA)

- 4. Racketeer Influenced and Corrupt Organizations (RIdOAAd E RSIT Y OE
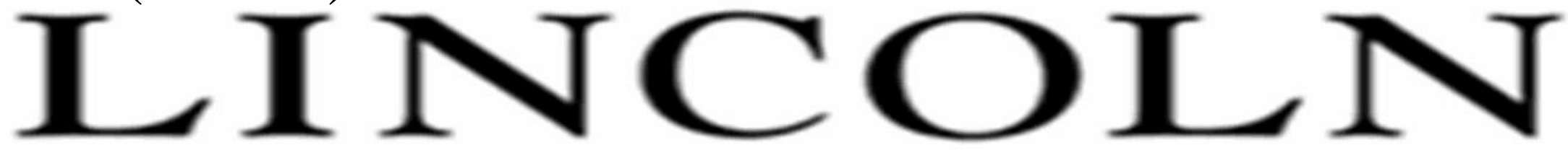
$>$ Alien Torts-Statute (ATS)

- Enacted in-1789, wastaflaty applieduntil 1980 in the Filartiga v. Pena-Irala case.

$>$ Torture Victim Protection-Act (TVPA)

- Greates a right for-xictims i cluding aliens of state sponsored torture and summary execution in other countries to sue in federal court.

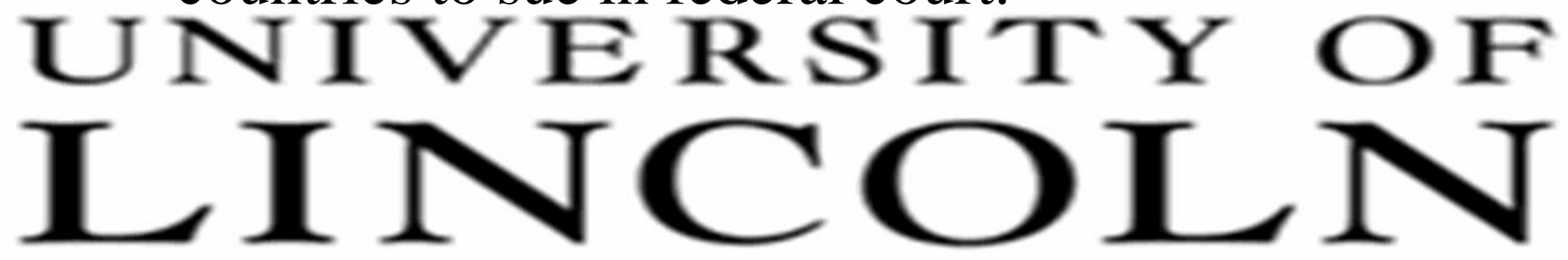


$>1996$ Congréss_enacted anti-terrorismànendments to the Foreign Sovereign Immunities Act (FSIA)

- The 1996 Amendment of the FSIA allows U.S. victims of terrofism to sue designated State sponsors of terrorism for their involvement in terrorism for spesified ferporist acts $>>$ Tran as a sponsor of Hezbollah and Hamas as well as for

U own terrorist actions as defendant $->$ applicable in corporate lawstits with a nexus
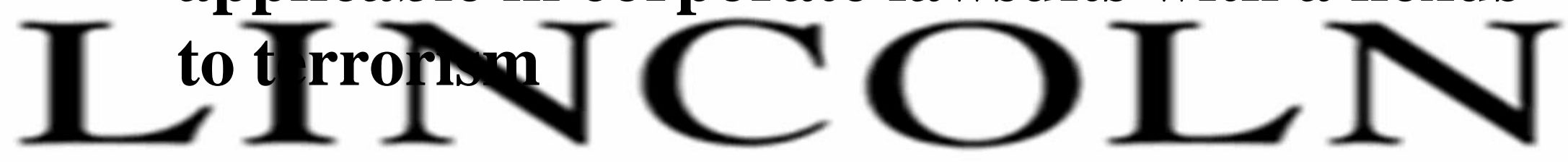


\section{$>2001$ Racketeer Influenced añd Corrupt Organizations}

(RICO) Act amended to include acts of terrorism:

- Allows civillawsuits against groups that have engaged in a pattern of racketeering activity, including murder, kidnapping, arson, robpery and fraud.

- Amendedbythe 2001 PAFROTAct toinclude acts of terrorism.

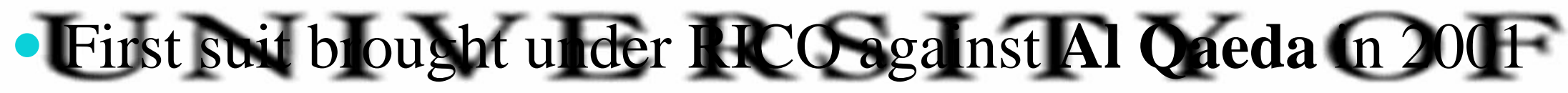
for their tan attak gne WorldFrode fenter.

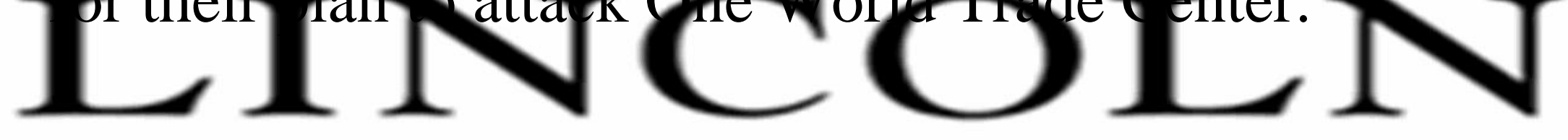




\section{onclusions and Reflections}

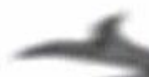

\section{s.}

- These developments do affect GHRR, despite the recent setbacks in finding a binding normative approach on the issue, as the failed Norms of 2003 and the watered down Ruggie guidelines exemplify.

- With the prospeet of seeing a potential reversal of the US litigation approach against the corporak aider and abettor for indirect liability, the overall prospect of seeing a binding normative regime on CHRR developing is rather dim.

- The potential rtsk and costs stemming from potentral CHRR breaches

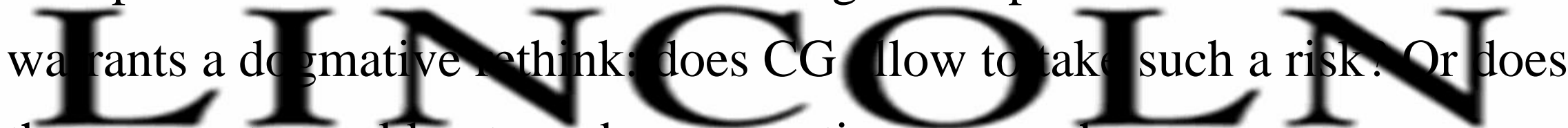
the corporate world not need a preemptive approach. 